\title{
ACE Inhibitory Activity, Total Phenolic and Flavonoid Content of Pereskia saccharose Griseb. Leaves Extract
}

\author{
Sarlina Jihan Lusiyanti, Katrin, Rissyelly*, Nuraini Puspitasari, Putu Gita Maya Widyaswari Mahayasih \\ Department of Pharmacognosy-Phytochemistry, Faculty of Pharmacy, Universitas Indonesia, Kampus Baru UI Depok 16424, Depok, INDONESIA.
}

Sarlina Jihan Lusiyanti, Katrin, Rissyelly*, Nuraini Puspitasari

Department of Pharmacognosy-

Phytochemistry, Faculty of Pharmacy, Universitas Indonesia, Kampus Baru UI Depok 16424, Depok, INDONESIA.

\section{Correspondence}

Rissyelly

Department of Pharmacognosy-Phytochemistry, Faculty of Pharmacy, Universitas Indonesia, Kampus Baru UI Depok 16424, Depok, INDONESIA.

Phone no: 6281314177284

E-mail: rissyelly@yahoo.com

\section{History}

- Submission Date: 21-12-2016;

- Review completed: 05-01-2017;

- Accepted Date: 04-02-2017.

DOI : 10.5530/pj.2017.2.49

Article Available online

http://www.phcogj.com/v9/i1

Copyright

(c) 2016 Phcog.Net. This is an openaccess article distributed under the terms of the Creative Commons Attribution 4.0 International license.

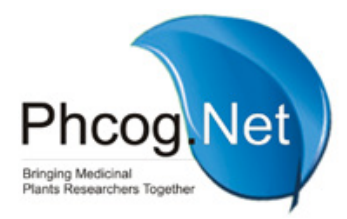

\begin{abstract}
Introduction: Angiotensin-converting enzyme inhibitors (ACEi) are drugs that can control hypertension. Pereskia saccharose Griseb. leaves have been used traditionally as antihypertensive. Objective: The objective of this study was to determine the antihypertensive activity through inhibition of ACE activity, the total phenolic content and total flavonoid content of the ethanolic extract of Pereskia saccharose Griseb. leaves and its fractions. Methods: Extraction was done by maceration with $80 \%$ ethanol and fractionation performed by liquid-liquid partition. Results: In vitro ACE inhibitory activity assay of the ethanolic extract using ACE Kit-WST Dojindo had $I C_{50}$ value of $3.448 \mu \mathrm{g} / \mathrm{mL}$ and ethyl acetate fraction had IC $C_{50}$ value of $1.714 \times 10-3 \mu \mathrm{g} / \mathrm{mL}$. Ethyl acetate contained the highest amounts of both TPC (72.991 $\pm 0.932 \mathrm{mg} \mathrm{GAE} / \mathrm{g}$ sample) and TFC (61.337 $\pm 1.612 \mathrm{mg}$ QE/g sample).

Conclusion: The results suggest that Pereskia saccharose Griseb. possess ACE inhibitory activity.
\end{abstract}

Key words: ACE inhibitor, Flavonoid, Pereskia saccharose Griseb, Phenolic.

\section{INTRODUCTION}

Hypertension has become one of the biggest health problems in the world because it has a high prevalence and has been associated with the increased risk of cardiovascular and kidney disease. ${ }^{1}$ Based on the WHO (2013), the global prevalence of hypertension was $40 \%$ and in 2025 is predicted as much as $60 \%$ of the total world population will suffer from hypertension. ${ }^{1,2}$

Antihypertensive drugs are needed to control blood pressure of hypertensive patients. Angiotensin-converting enzyme inhibitors (ACEi) are drugs to control hypertension. Angiotensin-converting enzyme (ACE) plays a role in converting angiotensin I to angiotensin II, which is responsible for triggering the mechanism of increased blood pressure. ${ }^{3}$

Many explorations on medicinal plants that can be used as an alternative treatment of hypertension have been done. Secondary metabolites in medicinal plants have been reported to have an inhibitory effect on ACE activity, including flavonoids, terpenoids, alkaloid, proanthocyanidin, hydrolyzed tannins, fatty acids, peptides, and xanthones. ${ }^{4}$

Pereskia saccharose Griseb. is one of the plants that has potential as a medicinal plant. Its leaves can be eaten raw or taken as a concoction brewed from fresh plant. Recent studies showed that Pereskia saccharose Griseb. leaves have been used empirically by the public as an antihypertensive. ${ }^{5}$ However, so far no studies have proven the efficacy and the antihypertensive mechanism of these plants scientifically. The objective of this study was to determine the antihypertensive activity through inhibition of ACE activity, the total phenolic content and total flavonoid content of the ethanolic extract of Pereskia saccharose Griseb. leaves and its fractions in solvents of different polarities.

\section{MATERIALS AND METHODS}

\section{Materials}

ACE Kit-WST A502 (Dojindo, Japan), Pereskia saccharose Griseb. leaves, captopril (Kimia Farma, Indonesia), gallic acid (Sigma-Aldrich, USA), quercetin (Sigma-Aldrich, USA), Folin-Ciocalteu (Merk, Germany), ethanol, n-hexane, ethyl acetate, and n-butanol (BRATACO, Indonesia). All other reagents were analytical grades.

\section{Preparation of Sample}

Plants materials were collected from Bogor, Indonesia and have been identified at Indonesian Institute of Sciences, Bogor, Indonesia. The leaves were thoroughly washed with tap water, sorted, cut, dried, and grinded into powder. Five hundred grams of powdered samples were extracted by maceration using $80 \%$ of ethanol $(7 \times 2.5 \mathrm{~L})$. The extracts were combined and concentrated using vacuum rotary evaporator to give crude extracts and calculated for a yield of extracts. Fifty grams of the crude extract were suspended in distilled water $(500 \mathrm{~mL})$ and partitioned successively with n-hexane, ethyl acetate, and n-butanol. The solvents were removed with vacuum rotary evaporator to produce dried fractions.

\section{Determination of ACE Inhibitory Activity}

The determination of ACE inhibitory activity was measured by a colorimetric method using ACE kitWST (Dojindo, Japan) according to the manufactur- 
er's protocol. The absorbance was read at $450 \mathrm{~nm}$ using PG Instruments Ltd. T80 microplate reader. Inhibition activity of ACE by the sample calculated according to the formula written on the manual procedure. The $\mathrm{IC}_{50}$ value was defined as the concentration of sample in $\mu \mathrm{g} / \mathrm{mL}$ required to reduce $50 \%$ of ACE activity, which was determined by regression analysis of ACE inhibition (\%) versus extract concentration. ${ }^{6}$

\section{Determination of Total Phenolic Content (TPC)}

Total phenolic content was measured using the modified Folin-Ciocalteu method adapted from Al-Saeedi and Hossain. ${ }^{7}$ The absorbance was read at wavelength $740 \mathrm{~nm}$. The analysis was done in triplicate. The total phenolic content was reported as total gallic acid equivalent per g sample (mg GAE/g).

\section{Determination of Total Flavonoid Content (TFC)}

Total flavonoid content was measured using the modified method adapted from Chang, et al. ${ }^{8}$ The absorbance was read at wavelength $434 \mathrm{~nm}$. The analysis was done in triplicate. The total flavonoid content was reported as total quercetin equivalent per g sample (mg QE/g).

\section{Statistical Analysis}

All the experiments were carried out in triplicate and the data were expressed as a mean \pm SD. All analyses were performed using GraphPad Prism version 7 (GraphPad Software, USA).

\section{RESULTS AND DISCUSSION}

Pereskia saccharose Griseb. leaves were extracted by maceration using $80 \%$ of ethanol. The yield extract obtained were $21.45 \%$. The crude extract then partitioned using n-hexane, ethyl acetate, and n-butanol. The highest percentage yield is from the n-butanol fraction with $14,26 \%$, followed by $n$-hexane fraction with $8 \%$. The ethyl acetate fraction had the lowest percentage yield (4.22\%). Those ethanolic extract and its fraction in n-hexane, ethyl acetate, and n-butanol then examined its ACE inhibitory activity, total phenolic content, and total flavonoid content.

\section{ACE Inhibitory Activity}

The ACE inhibitory activity of the ethanolic extract of Pereskia saccharose Griseb. leaves were analyzed using ACE Kit-WST (Dojindo, Japan). The assay is based on the detection of 3-hydroxybutyric acid (3HB) derived from 3-hydroxybutyryglycyl-glycyl-glycime (3HB-GGG) by the action of ACE and aminoacylase. ${ }^{9}$ Captopril was used as positive control. The ethanolic extract and all fractions were tested for the ACE inhibitory activity at $4.167 \mathrm{ug} / \mathrm{mL}$ final concentration. The ethanolic extract showed

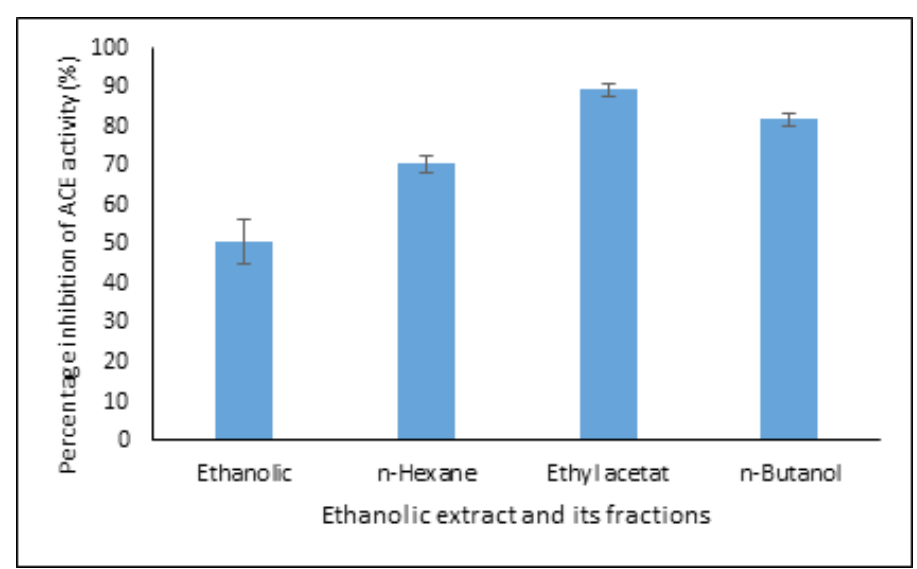

Figure 1: Percentage inhibition of ACE activity by ethanolic extract of Pereskia saccharose Griseb. leaves and its fractions at $4.167 \mathrm{ug} / \mathrm{mL}$ final concentration. high percentage inhibition with a value of $50.66 \%$ at $4.167 \mathrm{ug} / \mathrm{mL}$ final concentration. Among the three fractions, ethyl acetate fraction showed the strongest ACE inhibitory activity at $89.38 \%$, followed by n-butanol (81.83\%) and n-hexane (70.45\%) (Figure 1).

Ethyl acetate fraction which had the strongest ACE inhibitory activity was further investigated for their effect at a various concentration to obtain the $\mathrm{IC}_{50}$ values. The $\mathrm{IC}_{50}$ values of the ethanolic extract and ethyl acetate fraction are shown in Table 1 . The ethanolic extract gave a high activity with $\mathrm{IC}_{50}$ values of $3.448 \mathrm{ug} / \mathrm{mL}$. The ethyl acetate fraction also gave a high activity with $\mathrm{IC}_{50}$ values of $1.714 \times 10^{-3} \mathrm{ug} / \mathrm{mL}$. However, the ACE inhibitory activity of captopril as a positive control was more potent than the tested extract and fractions.

\section{Determination of Total Phenolic Content}

The determination of total phenolic content was performed using FolinCiocalteu method. The total phenolic content was expressed in term of gallic acid equivalent using the standard curve equation $y=0.1289 x+$ $0.0663, \mathrm{R}^{2}=0.9975$. The total phenolic content of ethanolic extract of Pereskia saccharose Griseb. leaves and its fractions results are showed in Figure 2.

The result showed that the ethanolic extract of Pereskia saccharose Griseb. leaves had a high total phenolic content $(23.754 \pm 0.399 \mathrm{mg} \mathrm{GAE} / \mathrm{g})$. Among the three fractions, ethyl acetate fraction contained the highest amount of TPC which is $72.991 \pm 0.932 \mathrm{mg} \mathrm{GAE} / \mathrm{g}$ sample, followed by an n-butanol fraction $(59.296 \pm 1.06 \mathrm{mg} \mathrm{GAE} / \mathrm{g})$ and n-hexane fraction (14.444 $\pm 0.19 \mathrm{mg} \mathrm{GAE} / \mathrm{g}$ ). The high phenolic content of ethyl acetate fraction may have contributed towards its ACE inhibitory activity.

\section{Determination of Total Flavonoid Content}

The determination of total flavonoid content was performed using a colorimetric method with $\mathrm{AlCl}_{3}$ as the chromogenic reagent. The total flavonoid content was expressed in term of quercetin equivalent using the standard curve equation $\mathrm{y}=0.0596 \mathrm{x}-0.0339, \mathrm{R}^{2}=0.9846$. The total flavonoid content of ethanolic extract of Pereskia saccharose Griseb. leaves and its fractions results are showed in Figure 3.

The result showed that the ethanolic extract of Pereskia saccharose Griseb. leaves had the total flavonoid content of $19.558 \pm 1.513 \mathrm{mg} \mathrm{QE} / \mathrm{g}$ extract. Among the three fractions, ethyl acetate fraction contained the highest amount of TFC which is $61.337 \pm 1.612 \mathrm{mg} \mathrm{QE} / \mathrm{g}$ sample, followed by $\mathrm{n}$-hexane fraction $(45.621 \pm 0.336 \mathrm{mg} \mathrm{QE} / \mathrm{g})$ and $\mathrm{n}$-butanol fraction $(27.053 \pm 2.002 \mathrm{mg} \mathrm{QE} / \mathrm{g})$.

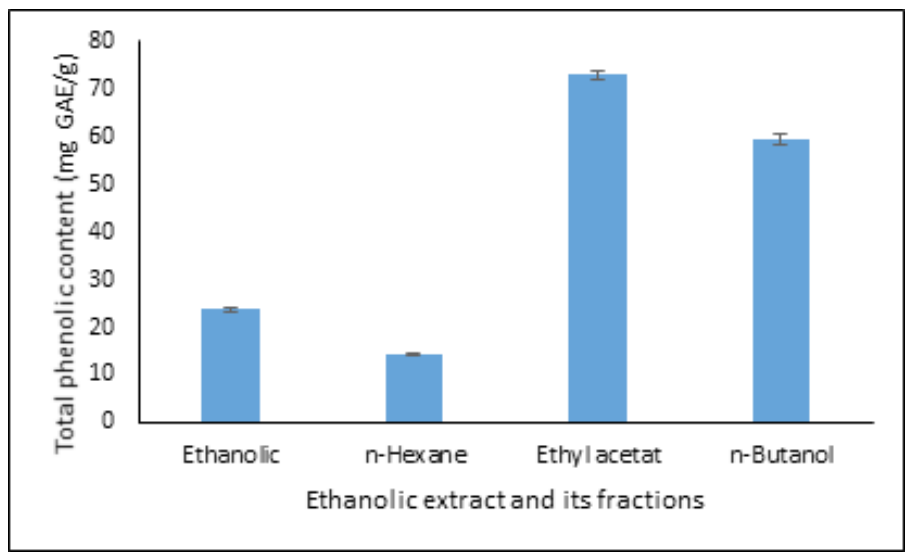

Figure 2: the Total phenolic content of ethanolic extract of Pereskia saccharose Griseb. leaves and its fractions. 
Table 1: Inhibition of ACE activity by ethanolic extract of Pereskia saccharose Griseb. leaves, ethyl acetate fraction and captopril at various concentration

$\begin{array}{cc}\text { Samples } & \mathrm{IC}_{50} \text { values }(\mathrm{ug} / \mathrm{mL}) \\ \text { Ethanolic extract } & 3.448 \\ \text { Ethyl acetate fraction } & 1.714 \times 10-3 \\ \text { Captopril (positive control) } & 1.13 \times 10-12\end{array}$

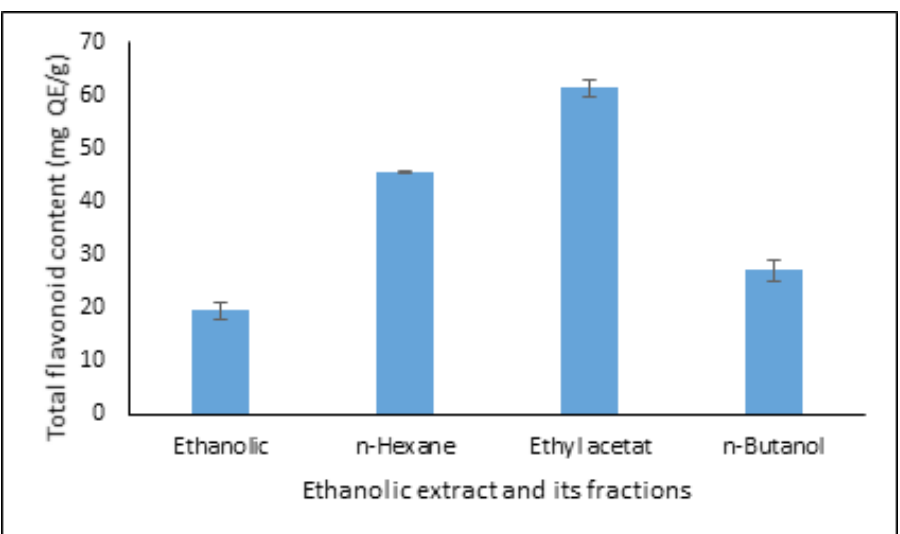

Figure 3: Total flavonoid content of ethanolic extract of Pereskia saccharose Griseb. leaves and its fractions.

\section{CONCLUSION}

Pereskia saccharose Griseb. leaves can be a good source of ACE inhibitory activity. Further studies need to be carried out to identify the active compounds for development contained in the leaves that lead to structures with the maximum inhibitory activities on ACE activity.

\section{ACKNOWLEDGMENT}

This study was supported by the Directorate of Research and Community Engagement, Universitas Indonesia via Hibah PITTA 2016.

\section{CONFLICT OF INTEREST}

The authors have no conflict of interest.

\section{ABBREVIATION USED}

ACE: Angiotensin-converting enzyme; TPC: Total phenolic content; TFC: Total flavonoid content.

\section{REFERENCES}

1. Kearney PM, Whelton M, Reynolds K, Muntner P, Whelton PK, He J. Global burden of hypertension: Analysis of worldwide data. Lancet. 2005;365(9455):217223.

2. WHO. A Global Brief on Hypertension, Swiss: WHO Press. 2013

3. Balasuriya BN, Rupasinghe HV. Plant Flavonoids as Angiotensin Converting Enzyme Inhibitors in Regulation of Hypertension. Functional Foods in Health and Disease. 2011;1(5):172-88

4. Loizzo MR, et al. Inhibition of Angiotensin Converting Enzyme (ACE) by Flavonoids isolated from Ailanthus excelsa (Roxb) (Simaroubaceae). Phytotherapy Research. 2007;21(1): 32-6.

5. Yen KP, Abdullah MSB, Syafri S, Raju SK, Yahya CAHC. A Preliminary Survey on the Medicinal Uses and Effectiveness of Pereskia bleo Used by People of Three Villages in the State of Kelantan, Malaysia. International Journal of Herbal Medicine. 2013;1(3):1-4

6. Dojindo Laboratories. (2013). ACE Kit - WST (100 tests) technical manual. 2 February 2016. https://www.dojindo.com/TechnicalManual/Manual_A502.pdf.

7. Al-Saeedi AH, Hossain MA. Total phenols, total flavonoids contents and free radical scavenging activity of seeds crude extracts of pigeon pea traditionally used in Oman for the treatment of several chronic diseases. Asian Pacific Journal of Tropical Disease. 2015;5(4):316-21.

8. Chang $\mathrm{CH}$, Yang MH, Wen HM, Chern JC. Estimation of Total Flavonoid Content in Propolis by Two Complementary Colorimetric Methods. Journal of Food and Drug Analysis. 2002;10(3):178-82.

9. Lam LH, Shimamura T, Ishiyama M, Ukeda H. Flow Injection Analysis of Angiotensin I-Converting Enzyme Inhibitory Activity with Enzymatic Reaction. Talanta. 2009;79:1130-4

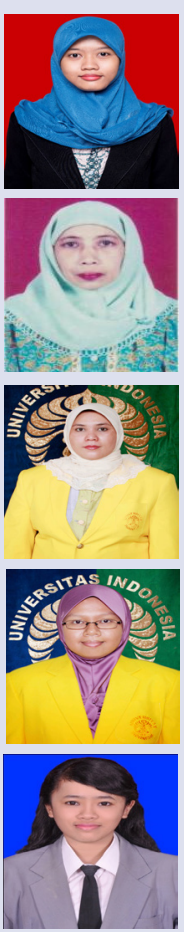

\section{ABOUT AUTHORS}

Sarlina Jihan Lusiyanti: Finished her bachelor in pharmacy, at Faculty of Pharmacy, Universitas Indonesia (Indonesia). Now she is a student at Apothecary Program at Faculty of Pharmacy, Universitas Indonesia.

Katrin: Completed her doctoral degree at Institut Teknologi Bandung (Indonesia). Currently, she focused her research on phytochemicals analysis in Indonesia's traditional medicinal plant.

Rissyelly: Finished her master program at Faculty of Pharmacy, Universitas Indonesia (Indonesia). Currently, she is taking her doctoral degree at Institut Teknologi Bandung. Her research focused on isolation and structural elucidation of compounds from medicinal plant.

Nuraini Puspitasari: Finished her master program at Faculty of Pharmacy, Institut Teknologi Bandung (Indonesia). She focused her research on pharmacology activity on natural product.

Putu Gita Maya Widyaswari Mahayasih: Finished her bachelor in pharmacy, at Faculty of Pharmacy, Universitas Jember. Now she is a master student at the Faculty of Pharmacy, Universitas Indonesia (Indonesia). Her master research focused on isolation of compound from Indonesia's medicinal plant.

Cite this Article: Lusiyanti SJ, Katrin, Rissyelly, Puspitasari N, Mahayasih PGMW. ACE Inhibitory Activity, Total Phenolic and Flavonoid Content of Pereskia saccharose Griseb. Leaves Extract. Pharmacogn J. 2017;9(2):285-7. 